\title{
Adiponectin multimers in patients with Barrett's Oesophagus
}

\author{
Mohammed Fakhraldeen*, Huseen Saad Mostafa**, Ghada Ali Abdulwahab*** \\ *Faculty of medicine, Mansoura University \\ **King Fahd hospital, Riadh ,Saudi Arabia \\ ***King Fahd hospital, Riadh, Saudi Arabia
}

\begin{abstract}
Objective

Barrett's oesophagus is associated with abdominal obesity. Adiponectin is a peptide that is secreted from adipocytes and circulates in three multimeric forms: low molecular weight (LMW), middle molecular weight (MMW), and high molecular weight (HMW). The antiinflammatory effects of adiponectin are specific to individual multimers, with the LMW being most anti-inflammatory. We investigated the possibility that circulating levels of adiponectin and its multimers would be associated with the risk of Barrett's oesophagus.
\end{abstract}

\section{Subjects and methods}

This study comprised patients diagnosed to have Barrett's oesophagus, and control subjects diagnosed to have gastrooesophageal reflux disease (GORD), all were diagnosed in the gastroenterology and endoscopy unit, King Fahd hospital, Riyadh, Saudi Arabia.

Plasma adiponectin levels and its multimers were evaluated for patients with Barrett's oesophagus and controls with GORD.

\section{Results}

There were 120 cases of Barrett's oesophagus and 250 GORD controls. Total adiponectin was not significantly associated with Barrett's oesophagus; low levels of LMW adiponectin and low LMW/total ratio were significantly present in patients with Barrett's oesophagus.

\section{Conclusion}

Low levels of LMW adiponectin are significantly associated with Barrett's oesophagus.

Key words: Barrett's oesophagus, GORD, abdominal obesity, Adiponectin.

\section{Introduction}

Oesophageal adenocarcinoma and its precursor, Barrett's oesophagus, are associated with obesity, particularly abdominal obesity (Corley et al 2007). Gastroesophageal reflux disease (GORD) is well described as a risk factor for both Barrett's oesophagus and oesophageal adenocarcinoma (Lagergren et al 1999). The effect of obesity on the development of Barrett's oesophagus and oesophageal adenocarcinoma may be due to an effect of obesity-promoting GORD (Lieberman et al 1997). Possible mechanisms include alterations in the anatomy of the gastrooesophageal junction and increased abdominal pressure, or confounding by diet (El-Serag et al 2006). however, since obesity is a risk factor for other cancers for which there are no known structural mechanisms (Calle et al 2003), at least some of the effect of obesity on the risk for Barrett's oesophagus may be metabolic and 
mediated by circulating factors related to obesity(de Martel et al 2007).

Adiponectin is a peptide secreted by adipose tissue (Rubenstein et al 2008), whose blood levels are inversely correlated with obesity (Arita et al 1999), It is involved in regulation of inflammation (Yokota et al 2000), and may suppress carcinogenesis by a number of mechanisms (Kandall et al 2008).

In the current study we evaluated patients with Barrett's oesophagus compared to patients with GORD and no Barrett's oesophagus, and estimated the levels of total adiponectin, and each of its multimers.

\section{Subjects and Methods}

This study was conducted on the gastroenterology and endoscopy unit, King fahd hospital, Riyadh, Saudi Arabia. Comparing the levels of adiponectin and its multimers between subjects with reflux symptoms and Barrett's oesophagus (patients group), and subjects with reflux symptoms but no Barrett's oesophagus (control group).

All enrolled subjects were between the ages of 20 and 70, and had undergone an upper endoscopy for investigation of GORD symptoms. All subjects reported classic GORD symptoms (heartburn, acid regurgitation or waterbrash) and had received a physician diagnosis of GORD.

Barrett's oesophagus was defined as the presence of both:

\section{Results}

A total of 370 subjects were included in this study, 120 with Barrett's esophagus (patient
1- Upward displacement of the squamocolumnar junction noted on endoscopy such that the junction of squamous and columnar mucosa is no longer at the interface of the most distal tubular oesophagus and the proximal gastric folds

2- Intestinal columnar metaplasia, as defined by the presence of columnar epithelium with goblet cells demonstrated on haematoxylin \& eosin staining, in at least one biopsy specimen from the tubular oesophagus. In equivocal cases, the documentation of goblet cells by alcian blue staining was considered positive for intestinalised metaplasia.

Controls for this study consisted of those patients with GORD who did not harbour endoscopically evident Barrett's oesophagus.

BMI and waist circumference were identified for patients and controls.

Blood was drawn after an overnight fast on the morning of the planned endoscopy and used for detection of the blood levels of adeponectin and its multimeres using the ELISA method (Hiroyuki et al,2006).

The associations between variables were examined using Pearson's correlation. Comparisons between groups were performed using the $\mathrm{t}$ test. Univariate logistic regression was performed for each variable for the outcome of Barrett's oesophagus.

group) and 250 with GORD (control group). 
Baseline characteristics of the patients and controls:

\begin{tabular}{|l|l|l|l|}
\hline & Barrett's esophagus cases & $\begin{array}{l}\text { GORD } \\
\text { Cases }\end{array}$ & P-value \\
\hline Number of subjects & 120 & 250 & \\
\hline Age ( years) & $57.5 \pm 11.5$ & $48.6 \pm 12.6$ & $<0.0001$ \\
\hline Gender & & $93(37 \%)$ & \\
Male & $80(67 \%)$ & $157(63 \%)$ & $<0.0001$ \\
Female & $40(33 \%)$ & $28.9+5.9$ & 0.46 \\
\hline BMI(kg/m2) & $29.2 \pm 5.3$ & $92.6 \pm 15.4$ & 0.18 \\
\hline Waist circumference(cm) & $93.3 \pm 14.3$ & & \\
\hline
\end{tabular}

1- Patients with Barrett's oesophagus were older with a higher proportion of men than GORD controls.

2-There was no difference in BMI between groups, but cases had slightly larger average waist circumference.

Adeponectin and its multimeres in patients and controls (mg|dl):

\begin{tabular}{|l|l|l|l|}
\hline & Barrett's esophagus cases & $\begin{array}{l}\text { GORD } \\
\text { Cases }\end{array}$ & P-value \\
\hline Total & $6.04 \pm 1.51$ & $5.85 \pm 1.36$ & 0.83 \\
HMW & $3.08 \pm 0.77$ & $2.54 \pm 0.63$ & 0.01 \\
MMW & $1.14 \pm 0.29$ & $1.33 \pm 0.32$ & 0.06 \\
LMW & $1.31 \pm 0.45$ & $2.18 \pm 0.54$ & 0.004 \\
LMW|total ratio & $0.34 \pm 0.08$ & $0.40 \pm 0.1$ & 0.0002 \\
\hline
\end{tabular}

This table shows that patients with Barrett's oesophagus have:

1-no significant difference in total plasma adiponectin.

2-slightly higher HMW adiponectin.

3-No significant difference regarding the MMW.

4-statistically significant difference regarding the low LMW adiponectin.

5-statistically significant low average ratio of LMW to total adiponectin. 


\section{Discussion}

We performed this study to evaluate the association between circulating levels of adiponectin multimers and the presence of Barrett's oesophagus. We did not find a significant association between the total level of adiponectin and the presence of Barrett's oesophagus, but we found that lower levels of the LMW adiponectin and low LMW|total ratio are significantly present in patients with Barrett's oesophagus.

It was found that low plasma levels of adiponectin are associated with an increased risk of Barrett's oesophagus among patients undergoing upper GIT endoscopy (Rubenstein et al 2008) and It was indicated that low circulating levels of adiponectin are associated with an increased risk of cancers of the colon, stomach, prostate, breast, and uterus (Kelesidis et al 2006). Specific receptors for adiponectin (AdipoR1 and AdipoR2) are found in oesophageal mucosa, and adiponectin induces apoptosis in a cell line of oesophageal adenocarcinoma (Konturek et al 2008). Adiponectin also inhibits leptininduced proliferation via AdipoR1 in cell lines of oesophageal adenocarcinoma (Ogunwobi et al 2008).

Adiponectin circulates in human blood in three multimeric complexes: trimers (low molecular weight, LMW), hexamers (middle molecular weight, MMW), and octadecamers (high molecular weight, HMW), (Suzuki et al 2007). Most of the actions of adiponectin on insulin resistance and coronary artery disease have been attributed to deficiencies in the circulating levels of the HMW multimer (Pajvani et al 2004). In contrast, the three multimers of adiponectin may have contrasting effects on inflammation. The HMW multimer induces the secretion of the proinflammatory cytokine interleukin 6 (IL6) from human monocytic cells, but the LMW multimer is anti-inflammatory, suppressing lipopolysaccharide- mediated release of IL6, and stimulating the secretion of the anti-inflammatory cytokine IL10 (Schober et al 2007). Low serum levels of HMW adiponectin are associated with the presence of metastases among patients with renal cell carcinoma (Horiguchi et al 2008), and with an increased risk for breast cancer (Korner et al 2007). The addition of even sub-physiological levels of HMW adiponectin to cell lines of prostate and hepatocellular carcinoma suppresses cell proliferation (Bub et al 2006).

Postulated mechanisms by which adiponectin can influence the risk of Barrett's oesophagus include:

1-Adiponectin can bind to growth factors, thereby inhibiting the growth factors' interaction with their cell membrane receptors (Gavrila et al 2003).

2-Adiponectin activates the 59-AMPactivated protein kinase (AMPK) pathway, thereby suppressing cell proliferation (Hotta et al 2000).

3-Adiponectin suppresses expression of cyclin D1 which is involved in neoplastic progression in Barrett's oesophagus (Otake et al 2005)

4- Adiponectin induces apoptosis in a cell line of oesophageal adenocarcinoma (Ebinuma et al 2006), and inhibits leptininduced proliferation in cell lines of oesophageal adenocarcinoma (Ogunwobi et al 2008).

Since Barrett's metaplasia is believed to be an aberrant response in the setting of erosive oesophagitis (Wang et al 2005), an attractive hypothesis is that normal levels of circulating LMW adiponectin are sufficient to suppress the inflammatory response to GORD (Bani-Hani et al 2000) or guide the healing response toward regeneration of squamous mucosa. LMW adiponectin might suppress the local expression of IL6 in oesophageal mucosa (Clement et al 2006); IL6 expression has been shown to be increased in the epithelium of Barrett's oesophagus (Reid et al 2003). In the setting of low levels of LMW adiponectin, the response to GORD might be directed toward a more severe oesophagitis and/or metaplasia into intestinal epithelium. 
Our finding that a low ratio of LMW to total adiponectin may be particularly associated with Barrett's oesophagus could be explained by the opposing effects of different multimers on inflammation.

Adiponectin is one of many circulating factors associated with obesity, and the observed effect of LMW adiponectin may be confounded by many factors, for instance:

1-IL6 downregulates adipocyte expression of adiponectin and circulating IL6 or other cytokines might instead be responsible for Barrett's metaplasia (Reid et al 2003).

2-Total adiponectin is inversely associated with insulin, and hyperinsulinaemia could instead be the causative factor related to Barrett's oesophagus (Gavrila et al 2003), however, the insulinsensitising effect of adiponectin appears to be specifically due to the HMW multimer (Jankowski et al 2000).

In our study, contrary to the observation that low levels of LMW adiponectin and low LMW to total adiponectin ratio are significantly present in patients with Barrett's oesophagus, a positive but weaker association was observed between high levels of HMW adiponectin and Barrett's oesophagus. So it can be postulated that the effect of adiponectin on Barrett's oesophagus may be mediated by protection by LMW adiponectin, promotion by HMW adiponectin or both (Clement et al 2006).

\section{Conclusion}

In conclusion, we found a strong inverse relationship between

circulating levels of LMW adiponectin and the presence of

Barrett's oesophagus among patients with GORD, this finding may has implications both for the pathogenesis of Barrett's oesophagus, as well as for potential use as a biomarker of the disease.

\section{Reference}

- Arita Y, Kihara S, Ouchi N, et al (1999). Paradoxical decrease of an adipose-specific protein, adiponectin, in obesity. Biochem Biophys Res Commun; 257:79-83.

- Bani-Hani K, Martin IG, Hardie LJ (2000). Prospective study of cyclin D1 overexpression in Barrett's esophagus: association with increased risk of adenocarcinoma. J Natl Cancer Inst; 92:1316-21.

- Bub JD, Miyazaki T, Iwamoto Y (2006). Adiponectin as a growth inhibitor in prostate cancer cells. Biochem Biophys Res Commun; 340:1158-66.

- Calle EE, Rodriguez C, Walker-Thurmond K (2003). Overweight, obesity, and mortality from cancer in a prospectively studied cohort of U.S. adults. New Engl J Med ;348:1625-38.

- Clement G, Braunschweig R, Pasquier N (2006). Alterations of the Wnt signalling pathway during the neoplastic progression of Barrett's esophagus. Oncogene

$$
\text { ; 25:3084-92. }
$$

- Corley DA, Kubo A, Levin TR (2007). Abdominal obesity and body mass index as risk factors for Barrett's esophagus. Gastroenterology; 133:34-41; quiz 311.

- De Martel C, Haggerty TD, Corley DA (2007). Serum ghrelin levels and risk of subsequent adenocarcinoma of the esophagus. Am J Gastroenterol ; 102:1166-72.

- Ebinuma H, Miyazaki O, Yago H (2006). A novel ELISA system for selective measurement of human adiponectin multimers by using proteases. Clin Chim Acta

$$
\text { ; 372:47-53. }
$$

- El-Serag HB, Tran T, Richardson P (2006). Anthropometric correlates of intragastric pressure. Scand J Gastroenterol ; 41:887-91.

- Gavrila A, Chan JL, Yiannakouris (2003). Serum adiponectin levels are inversely associated with overall and central fat distribution but are not directly regulated by acute fasting or leptin administration in humans: cross-sectional and interventional studies.

J Clin Endocrinol Metab ; 88:4823-31.

- Hiroyoki Ebinuma, Osamu Miyazaki, Hirokazu Yago, Kazuo Hara, Toshimasa Yamaushi (2006). A novel ELISA system for selective measurement of human adiponectin multimers by using proteases.Clinical Chimica Acta:;372,1-2:47-53

- Horiguchi A, Ito K, Sumitomo M (2008). Decreased serum adiponectin levels in patients 
with metastatic renal cell carcinoma. Japan J Clin Oncol ; 38:106-11.

- Hotta K, Funahashi T, Arita Y (2000). Plasma concentrations of a novel, adiposespecific protein, adiponectin, in type 2 diabetic patients. Arterioscl, Thromb Vascul Biol ;20:1595-9.

- Jankowski JA, Harrison RF, Perry I (2000). Barrett's metaplasia. Lancet ;356:2079-85.

- Kelesidis I, Kelesidis T, Mantzoros CS (2006). Adiponectin and cancer: a systematic review. Br J Cancer ; 94:1221-5.

- Kendall BJ, Macdonald GA, Hayward NK (2008). Leptin and the risk of Barrett's oesophagus. Gut ; 57:448-54.

- Konturek PC, Burnat G, Rau T (2008). Effect of adiponectin and ghrelin on apoptosis of barrett adenocarcinoma cell line. Dig Dis Sci ; 53:597-605.

- Korner A, Pazaitou-Panayiotou K, Kelesidis (2007). Total and high-molecularweight adiponectin in breast cancer: in vitro and in vivo studies. J Clin Endocrinol Metab ; 92:1041-8.

- Lagergren J, Bergstrom R, Lindgren A (1999). Symptomatic gastroesophageal reflux as a risk factor for esophageal adenocarcinoma. New Engl J Med ; 340:825-31.

- $\quad$ Lagergren J, Bergstrom R, Nyren O (1999). Association between body mass and adenocarcinoma of the esophagus and gastric cardia. Ann Intern Med

$$
\text { ; 130:883-90. }
$$

- Lieberman DA, Oehlke M, Helfand M (1997). Risk factors for Barrett's esophagus in community-based practice. GORGE consortium. Gastroenterology Outcomes

Research Group in Endoscopy. Am J Gastroenterol ; 92:1293-7.

- Ogunwobi OO, Beales IL (2008). Globular adiponectin, acting via adiponectin receptor-1, inhibits leptin-stimulated oesophageal adenocarcinoma cell proliferation. Mol Cell

Endocrinol ; 285:43-50.

- Otake S, Takeda H, Suzuki Y (2005). Association of visceral fat accumulation and plasma adiponectin with colorectal adenoma: evidence for participation of insulin resistance. Clin Cancer Res; 11:3642-6.

- Pajvani UB, Hawkins M, Combs TP (2004). Complex distribution, not absolute amount of adiponectin, correlates with thiazolidinedione-mediated improvement in insulin

sensitivity. J Biol Chem ; 279:12152-62.

- Rubenstein J, Dahlkemper A, Kao J (2008). A pilot study of the association of low plasma adiponectin and Barrett's esophagus. Am J Gastroenterol ; 103:1358-64.

- Schober F, Neumeier M, Weigert (2007). Low molecular weight adiponectin negatively correlates with the waist circumference and monocytic IL-6 release. Biochem Biophys Res Commun ; 361:968-73

- Suzuki S, Wilson-Kubalek EM, Wert D (2007). The oligomeric structure of high molecular weight adiponectin. FEBS Lett ; 581:809-14.

- Wang Y, Lam K, Xu J (2005). Adiponectin inhibits cell proliferation by interacting with several growth factors in oligomerizationdependent manner. J Biol Chem ; 280:18341-7.

- Yokota T, Oritani K, Takahashi I (2000). Adiponectin, a new member of the family of soluble defense collagens, negatively regulates the growth of myelomonocytic progenitors and the functions of macrophages. Blood ; 96:1723-32. 


\section{الاديبونكتين فى مرضى باريت بالمرئ}

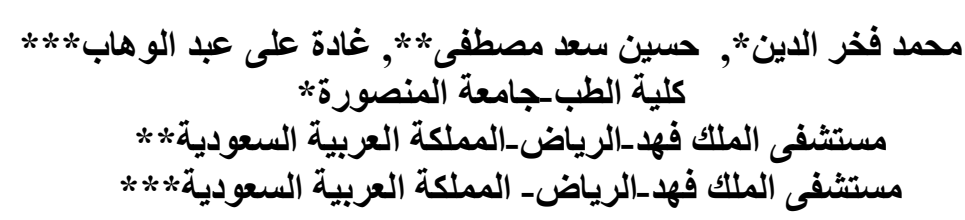

يعتبر مرض باريت من الامر اض التى تصاحب السمنة و يفرز عنصر الادييونكتين من الخلايا الدهنية على ثلاث اجز اء رمنخفض رمتوسط , ومرتفع الوزن الجزيئى. برئ.

ويعتبر المنخفض هو اكثر هم من حيث الخاصية المضادة للالتهاب.ولقد تمت الدر اسة لبحث العلاقة بين الاديبونكتين و مرض باريت. و اجريت الدراسة على مرضى يثكون من اعر اض مرض الارتجاع وتم تقسيمهم الى مجموعة الحالات (120 ) وثبت اصابتهم بمرض باريت و المجموعة الضابطة (250 ) بون مرض برضيك باريت.

وتمت الدر اسة فى وحدة الجهاز الهضمى و المناظير بمستشفى الملك فهد,الرياض,المملكة العربية السعودية.وتم قياس عنصر الاديبونكتين فى كلا المجمو عتين.

و تبين ان النسبة الكلية للادييونكتين لا تختلف فى كلا المجمو عتين ولكن يوجد انخفاض مهم احصائيا فى نسبة الجزء القليل الوزن الجزيئى و ايضا فى النسبة بين الجزء القليل الوزن الجزيئى و النسبة الكلية فى مرضى باريت. و نخلص من الدراسة الى اهمية الاديبونكثين قليل الوزن الجزيئى فى مرضى باريت حيث يمكن ان يكون له فائدة 